\title{
Submandibular Gland Acinic Cell
}

\section{Carcinoma}

National Cancer Institute

\section{Source}

National Cancer Institute. Submandibular Gland Acinic Cell Carcinoma. NCI Thesaurus.

Code C5934.

An adenocarcinoma with serous acinar cell differentiation that arises from the submandibular gland. 